\title{
Self-perceived preparedness of dental school graduates and the impact of COVID-19 pandemic on their confidence
}

Islam Abd Alraheam ( $\square$ islam.raheam@gmail.com )

The University of Jordan School of Dentistry https://orcid.org/0000-0002-7293-3112

\section{Mays A. Alashqar}

The University of Jordan School of Dentistry

\section{Susan Hattar}

The University of Jordan School of Dentistry

\section{Abeer AlHadidi}

The University of Jordan School of Dentistry

\section{Alaa Alhaddad}

The University of Jordan School of Dentistry

\section{FA Sawair}

The University of Jordan School of Dentistry

\section{Research article}

Keywords: Undergraduate Dental Education, Skills/Doctoring, General Dentistry, COVID-19, Confidence, Preparedness

Posted Date: November 3rd, 2020

DOI: https://doi.org/10.21203/rs.3.rs-49483/v3

License: (c) (1) This work is licensed under a Creative Commons Attribution 4.0 International License. Read Full License

Version of Record: A version of this preprint was published at Saudi Journal of Oral Sciences on January 1st, 2021. See the published version at https://doi.org/10.4103/sjos.SJOralSci_5_21. 


\section{Abstract}

Background. To study self-perceived preparedness of dental school graduates and the impact of COVID-19 on their preparedness.

Method. An online survey was designed and sent electronically to students who were graduating in 2020, dentists who graduated in 2019 and were doing their prelicensure training, and dentists who graduated before 2019. Four- point Likert scale was used to assess participants' perception.

Results. There were 209 participants responded to the online questionnaire. The mean total preparedness score (TPS) for the 209 participants was 97.6 (SD \pm 9.7 ) with a range of 69 to 120. The mean TPS of the different classes of participants was 99.5 for the class graduated before 2019, 98.1 for the 2020 class, and 95.1 for the 2019 class. Participants felt they are confident and extremely confident doing the majority of the required competencies. Weakness was mainly reported in surgical extraction for 2020 graduates due to the 8 weeks loss of their training. COVID-19 had considerable impact on $59.7 \%$ of the participants and marginal to no impact on $40.3 \%$. The highest prevalence of those who thought it had some to severe impact on their confidence were those who graduated in year 2019 (73.4\%).

Conclusions. The graduates of University of Jordan felt confident in performing the majority of general dentistry procedures. COVID-19 pandemic negatively impacted the confidence of all the classes of participants even those graduated before 2019.

\section{Background}

Dental education is regarded as a complex, demanding and often stressful pedagogical procedure. Dental educational environment is expected to enable students to acquire the necessary theoretical, clinical experiences and to expose them to continuous self- assessment opportunities equivalent to the environment in which they are likely to be practicing dentistry. ${ }^{1,2}$ The quality of any dental program is reflected by assessing graduating students' professional preparedness.

The dental school in the University of Jordan is a 5 year program qualifying students for the Doctor of Dental Surgery degree. After graduation, the graduates must undergo a pre-licensure training for 12 months to get their license to practice general dentistry. The school implemented a problem based learning curriculum and a competency-based assessment grading tool for each branch of dentistry in 2010. Competence comprises an integration of knowledge, skills and attitudes indicating a capability to perform professional tasks safely and ethically. ${ }^{3}$ This curriculum and grading tool are focused on the skills of examination and treatment planning to assure students preparedness for comprehensive patient care after graduation. It also help them define their weakness in specific competency, therefore, work harder to develop themselves in this specific area. Positive feedback regarding this teaching strategy from the teaching faculties were verbally reported but no studies were done to evaluate the effectiveness of this strategy on the dental students' confidence and preparedness to perform general dentistry after graduation. 
In the literature multiple studies were done to evaluate the self-perceived preparedness of the graduates. Some of these studies used a self-designed survey questions, ${ }^{4,5,6}$, while others used the Dental Undergraduate Preparedness Assessment Scale. ${ }^{7,8}$ The findings of those studies indicate that dental schools usually succeed in graduating dentists who are prepared for performing most of the simple and basic dental procedures.

COVID-19 has had many challenges for dentistry some of which may have further long term impacts on clinical practice, dental education and dental research. ${ }^{9}$ The Occupational Safety and Health Administration (OSHA) in the United States classified dentist in the very high-risk category because of the potential of exposure to coronavirus through aerosol generating procedures. ${ }^{10-12}$ Therefore, this pandemic which affected almost all the countries in the world caused paralysis in clinical education in dental schools and hospitals. Impact on education can be directly reflected on graduates' preparedness. Suspension of educational activities can lead to frustration among students and faculties. Shifting to on-line learning was a good strategy to teach the didactic theoretical courses but it could not replace the hands-on teaching where the students usually gain and develop their skills and manual dexterity to build their confidence. Additionally, the quality of online education is a critical issue that needs proper attention. ${ }^{13,14}$ Some dental educators recommend dental school to invest in haptic technology to improve psychomotor skills and also in faculty training for teaching through technology. ${ }^{11}$ The effectiveness of utilizing haptic technology in clinical education is not proven and more research is needed in this area. ${ }^{13,15}$ It is been suggested that the model of dental education should be innovated to suit different situations and novelty intelligent technology should be applied for future dental education. ${ }^{16}$ Dental schools around the world tried their best using web-based seminars, lectures, and case discussions on multiple platforms to compensate the students for that lost part of education which could impact their confidence and preparedness.

The COVID19 outbreak has created a tremendous level of stress among students and dentists. This stress may lead to unfavorable effects on the learning and psychological health of students. ${ }^{13}$ Fear of the unknown can develop anxiety in healthy people as in those with previous mental health problems. ${ }^{17}$ It might also have a serious impact on the careers of this years' university graduates. ${ }^{13}$ Dentists are exposed to a high psychological tension from the fear of getting infected with COVID-19 and the frequent appointment cancellation from patients. ${ }^{17,18,19}$

The dental students at University of Jordan lost 8 weeks of their clinical training, which counts for $26.7 \%$ of their clinic time in their senior year. The curriculum after COVID-19 was almost similar to the one used before COVID-19 since all students were required to successfully complete the required competencies. For students who were not able to successfully complete the required competencies for graduation, the dental school established a policy for senior students to show up to the preclinical labs to practice and successfully perform those competencies on dentoform, taking in consideration social distancing and strict cross infection control measures. The supervising faculties were able to assure that all students successfully passed the required competencies before they can get into the final exams which were done through online OSCE and oral exams. On the other hand, all the students were able to complete the didactic courses through the online teaching methods and platforms such as Zoom and Microsoft teams. 
Dentists who were doing their pre-licensure training in the University of Jordan hospital were also affected by the COVID-19 lockdown. They lost around 8 weeks of their clinical training. They then went back to the training after the hospital clinics were opened.

Dentists in Jordan were forced to close their clinics for two months then they were allowed to treat the emergency cases only. The ministry of health then had allowed dentists to open normally after 3 months of closure and limited practice. All of the continuing education hands-on courses were cancelled and only online lectures were given to the dentists mainly through the Jordanian Dental Association and different other platforms.

This research was designed to study the self-perceived preparedness of University of Jordan graduates and the impact of COVID-19 on this preparedness.

\section{Methodology}

Ethical approval to conduct the study was obtained from the School of Dentistry and the Academic Research Committee at the University of Jordan. An on-line survey was designed by the research team in English language since it is the teaching language in the dental school. The survey (appendix 1) was selfdesigned and composed of multiple sections. The demographic section covered information on gender, GPA and status of the participants (student, dentist graduated in 2019, and dentist graduated before 2019). The next sections composed of questions about the confidence of performing 28 competencies in examination and treatment planning, restorative (operative, endodontics and prosthodontics), periodontics, oral surgery, pediatric dentistry, and orthodontics. The last section had questions about communication skills and the impact of COVID-19 on participants' self-perceived confidence and preparedness. Four- point Likert scale was used to assess the student preparedness and confidence (Extremely not Confident, Not confident, Confident, Extremely confident). Responses of (Extremely not confident) were allocated a score of one; (Not confident) a score of two, (Confident) a score of three, and (Extremely confident) a score of four. The total score for the preparedness scale ranged from 0 to 120 .

The survey was validated by an experienced professor in the school then tested by couple of participants. It was sent electronically to students who were graduating in $2020(n=197)$ and to the ones who graduated in 2019 and they were doing their pre-licensure training $(n=202)$ and to dentists who graduated between 2010 and $2019(n=90)$. The participation was voluntary and anonymous. The invitation letter was accompanied by a participant information sheet summarizing the aims of the study. Consents of the participants were obtained before they could start answering the survey. The survey was opened for the participants for 6 weeks. A reminder was sent after three weeks.

\section{STATISTICAL ANALYSIS}

Statistical analysis was performed using SPSS for Windows release 16.0 (SPSS Inc., Chicago, IL, USA). Descriptive statistics including total preparedness score (TPS) were generated. Normality of TPS was tested by numerical (skewness, kurtosis, z values, and Shapiro-Wilk test) and visual outputs (Histograms, normal Q-Q plots and Box plots). These methods showed that TPS was normally distributed and, therefore, 
Independent samples T test, One-Way-ANOVA, and Bonferroni Post Hoc test were used to compare mean TPS between the different groups. For each competency, Chi-square and Fisher's Exact tests were used to examine differences between the different years of graduation. The significance level was stated as $P<$ 0.05 .

\section{Results}

There were 209 participants responded to the online questionnaire yielding $43 \%$ response rate. The study sample was composed of 82 (39.2\%) dental students who were graduating in 2020 with a response rate of $42 \%, 64$ (30.6\%) dentists who graduated in 2019 and were doing their pre-licensure training with a response rate of $32 \%$, and $63(30.2 \%)$ dentists who graduated before 2019 with a response rate of $70 \%$. They were composed of 171 (81.8\%) females and 38 (18.2\%) males.

The mean total preparedness score (TPS) for the 209 participants in this study was 97.6 (SD \pm 9.7$)$ with a range of 69 to 120 . The mean TPS was not significantly affected by gender or GPA of the participants $(P>0.05)$. The mean TPS of the different classes of participants is shown in Table 1. The mean TPS was significantly affected by class of participants $(P=0.032)$; graduates before 2019 had the highest TPS followed by those graduated in 2020 and the lowest TPS was for graduates of 2019. However, this effect was mainly noticed when graduates of 2019 were compared with graduates before $2019(P=0.031)$. The differences in mean TPS between those who graduated in 2020 and who graduated in $2019(P=0.20)$ and between those who graduated in 2020 and who graduated before $2019(P=1.0)$ were not statistically significant.

The response of the different graduates to each competency is shown in Table 2. The response as four grades (extremely not confident, not confident, confident, and extremely confident) was compared. Graduates before year 2019 had significantly higher level of extreme confidence compared with other graduates in skills of examination, simple treatment planning, direct restorations, profound local anesthesia, examination and treatment planning on a pediatric patient, oral hygiene instructions and dietary advice for a pediatric patient, and extraction of a primary tooth. In contrast, graduates of 2020 had significantly higher level of extreme confidence compared with other graduates in skills of rubber dam isolation, root canal treatment for a molar tooth, secondary impression for complete denture patient, and bite registration for complete denture patient.

A significant percentage of graduates, regardless of the year of graduation, thought they were not confident in performing some competencies. These include: surgical extraction (58.9\%), clinical remount and insertion of a removable prosthesis (55.5\%), oral cancer screening (54.1\%), surveying and designing of a Co-Cr RPD (34\%), comprehensive treatment planning including indirect restorations, removable prosthesis and implants (30.1\%), suturing (29.7\%), root canal treatment for a molar tooth $(26.8 \%)$, bite registration for complete denture patient (24.4\%), and crown preparation (20.1\%).

The different graduates were also asked if COVID-19 impacted their level of confidence in performing general dentistry procedures. Of the respondents, $17.5 \%$ thought it had a severe impact, $42.2 \%$ thought it 
had some impact, $20.9 \%$ thought it had a marginal impact, while $19.4 \%$ thought it had no impact. The different years of graduation were compared as shown in Figure 1. Of the graduates before year 2019, $55.7 \%$ thought it had some to severe impact on their confidence in performing general dentistry procedures. The highest prevalence of those who thought it had some to severe impact on their performance were those who graduated in year 2019 (73.4\%), while the lowest prevalence of those who thought it had some or severe impact on their performance were graduates of the year $2020(51.9 \%)(P=0.024)$. This opinion was not significantly affected by gender or GPA of the graduates.

\section{Discussion}

In this study three different classes were targeted; the dental students who were graduating in 2020, dentists graduated in 2019 and they were doing their prelicensure training, and dentists who graduated before 2019. All of the groups had similar dental school curriculum except that the classes graduated before 2019 had $10 \%$ more clinical sessions in their training because the number of students per class was less compared to the graduates of 2019 and 2020 classes.

The design of the survey was extracted from the required competencies for graduation of students from the school of dentistry from University of Jordan.

The range of the TPS for all the participants is $69-120$ with a mean of 97.2 is considered satisfactory. Differences in TPS were noticed between the classes. The highest TPS was found for the dentists who graduated before 2019. One of the reasons could be that neither their pre-graduation clinical training nor their prelicensure training was affected by COVID-19.

Graduates before 2019 had higher level of confidence in multiple competencies compared to the other two classes. That could be related to the fact that those dentists have been practicing dentistry for multiple years. Their responses might have been influenced by their clinical experience in clinical practice. The concept of students considered themselves competent based on their previous experience of the task was mentioned previously in the literature. ${ }^{20}$ Additionally, the classes graduated before 2019 had $10 \%$ more clinical sessions in their training which could have slightly increased their level of confidence and preparedness. In the study conducted by Manakil, the authors found that $71.4 \%$ of students suggested that an increase of the number of clinical sessions would enhance their educational experience and yield more confidence. $^{21}$

The results of this study showed that $12.2 \%$ of 2020 class, and around $6 \%$ of the other two classes perceived themselves as extremely not confident performing surgical extraction. This in one of the procedures which is considered complex and the new graduates usually do not have adequate confidence to perform. ${ }^{5,6}$ Those findings agree with D.J.Scho" nwetter's findings where he reported that recent graduates were least confidence in implantology, orofacial pain, trauma and surgical management and C.K.Y.Yiu findings where he concluded that there is apparent deficiencies of training in oral and maxillofacial surgery in the institution where the study was conducted. ${ }^{5,22}$ Although the 2020 class lost 8 weeks of their clinical training due to COVID-19 pandemic and could not continue their surgical extraction 
competency, $32.9 \%$ of them felt confident and extremely confident performing such procedure, which could indicate students over estimating their abilities.

When reviewing the results on oral cancer screening, the majority of our graduates reported being not confident and extremely not confident performing this task. Fortunately, by the time this manuscript was being prepared, the diagnostic science department introduced a special module in their curriculum to enhance the upcoming students' skills in oral cancer screening. Participants' low confident level in oral cancer screening was also reported in a national study done in the UK. ${ }^{23}$

Concerning removable prosthodontic tasks our students demonstrated lower level of confidence compared to restorative procedure tasks. That could be due to the lower number of clinical sessions of removable prosthodontic clinics compared to operative and fixed prosthodontic clinics. The high students' confidence in making secondary impression for a complete denture patient is most probably because it is the required task for the final exam of the removable prosthodontic clinic. Students tend to focus on this competency in particular to ensure doing it correctly in the final exam.

More than $90 \%$ of the participants of this survey reported being confident and extremely confident in the following modules: examination and treatment planning, restorative dentistry (profound local anesthesia, rubber dam isolation, direct restorations, and root canal treatment for a single root tooth), prevention and pediatric dentistry, periodontics and communication skills. Those results suggest that dental graduates of University of Jordan are prepared to perform the basic general dentistry procedures.

Around $60 \%$ of the participants reported that COVID-19 had some to severe impact on the level of confidence in performing general dentistry procedures. The lockdown that happened due to COVID-19 lead to almost two months loss of performing general dentistry. The impact affected all the classes of the participants with the highest impact on the dentists who graduated in 2019 and they were doing their prelicensure training (73.4\%) and the lowest on the students who were graduating in 2020 (51.9\%). The lower level of impact on 2020 class might be related to the possibility that students might be unaware of their proper level of clinical expertise. Additionally, psychological impact of this pandemic on students' wellbeing and the stress of graduation during COVID-19 might also create a psychological defensive response from the participants who were graduating in 2020 affecting the accuracy of their answers about their confidence level. On the other hand, graduates with experience can better identify their strengths and weaknesses and could give more accurate answers regarding what they know and what they do not know. According to medical education literature, the process of oneself assessment is complicated, and by its very nature can never be objective or free from the beliefs and values individuals hold about themselves. ${ }^{20}$ Therefore self-evaluation instruments are best used to help individuals analyze their work practices and to promote reaction on performance. They should not be used to judge the accuracy of the individual's evaluation. ${ }^{20} \mathrm{~A}$ good example on that is a study reported that graduates perceived their competency to be excellent in the four areas (treatment planning; community-based skills; management, administrative skills, and personal management; and professional development skills), on the other side, employers of those graduates felt that these are the areas that are of concern and needed attention. ${ }^{24}$ 
The highest level of impact reported by the 2019 class. Those participants might felt that the interruption which happened in their training did not allow them to work on their weaknesses as they planned.

More than half of the participants who graduated before 2019 reported that COVID-19 had some to severe impact in their confidence performing general dentistry procedures. This group actually neither their undergraduates training nor their pre-licensure training was affected by the lockdown. The learning opportunity they missed is basically the continuing education practical courses which were cancelled due to the lockdown. The impact on the confidence can be due to the possibility that those dentists are exposed to a high psychological tension from the fear of getting infected with COVID-19 and transmitting the disease to their family members and between their patients and the stress that comes from the financial aspect of their career.

Interestingly, GPA of the graduates had no effect on the level of confidence of the participants. That could be explained by the fact that the GPA is cumulative from both of the didactic and clinical courses. As found in the dental literature the correlation between the student's performance in the didactic and clinical courses is weak. ${ }^{25}$ Furthermore, confidence can be directly associated with social skills and intelligence which is usually not precisely covered in the grading criteria.

There are multiple limitations of this study. One of the main limitations is the possibility that graduates before 2019 answers could be highly affected by the clinical experience they gained through their practice and not based on the skills they graduated with from the dental school. One more limitation is the low response rate from the students who were graduating in 2020 and the ones who graduated in 2019. The survey was conducted during the final exams of the graduating students which could justify the low response rate from them.

\section{Conclusions}

1) The graduates of University of Jordan felt confident in performing the majority of general dentistry procedures.

2) COVID-19 pandemic negatively impacted the confidence of all the classes of participants even those graduated before 2019 .

3) Modifications in our dental curriculum might be warranted for the competencies that demonstrated low level of confidence.

\section{Declarations}

\section{Competing interests}

None of the authors has conflict of interest.

\section{Funding}


This study was not supported by any fund.

\section{Acknowledgements}

The authors acknowledge all the students/ dentists who participated in this survey.

\section{References}

1. Divaris K, Barlow PJ, Chendea SA, Cheong WS, Dounis A, Dragan IF, et al. The academic environment: The students' perspective. Eur J Dent Educ. 2008;12(SUPPL. 1):120-30.

2. Haghparast N, Sedghizadeh PP, Shuler CF, Ferati D, Christersson C. Evaluation of student and faculty perceptions of the PBL curriculum at two dental schools from a student perspective: A cross-sectional survey. Eur J Dent Educ. 2007;11(1):14-22.

3. Chuenjitwongsa S, Oliver RG, Bullock AD. Competence, competency-based education, and undergraduate dental education: a discussion paper. Eur J Dent Educ. 2018;22(1):1-8.

4. Arena G, Kruger E, Holley D, Millar S, Tennant M. Western Australian dental graduates' perception of preparedness to practice: a five-year follow-up. J Dent Educ. 2007;71(9):1217-22.

5. Yiu CK, McGrath C, Bridges S, Corbet EF, Botelho M, Dyson J, et al. Graduates' perceived preparedness for dental practice from PBL and traditional curricula. J Dent Educ. 2011;75(9):1270-9.

6. Gilmour AS, Welply A, Cowpe JG, Bullock AD, Jones RJ. The undergraduate preparation of dentists: Confidence levels of final year dental students at the School of Dentistry in Cardiff. Br Dent J. 2016;221(6):349-54.

7. Mat Yudin Z, Ali K, Wan Ahmad WM, Ahmad A, Khamis MF, Brian Graville Monteiro NA, et al. Selfperceived preparedness of undergraduate dental students in dental public universities in Malaysia: A national study. Eur J Dent Educ. 2020;24(1):163-8.

8. Ali K, Slade A, Kay E, Zahra D, Tredwin C. Preparedness of undergraduate dental students in the United Kingdom: a national study. Br Dent J. 2017;222(6):472-7.

9. Barabari P, Moharamzadeh K. Novel Coronavirus (COVID-19) and Dentistry-A Comprehensive Review of Literature. Dentistry journal. 2020;8(2):53.

10. Educational Debt. American Dental Education A. https://www.adea.org/GoDental/Money_Matters/Educational_Debt.aspx. Accessed April 18, 2020.

11. Iyer P, Aziz K, Ojcius DM. Impact of COVID-19 on dental education in the United States. J Dent Educ. 2020;84(6):718-22.

12. S.Department of Labor, Occupational Safety and Health Administration. Guidance on preparing workplaces for COVID-19. OSHA 3990-03 2020. Accessed April 18, 2020.

13. Sahu P. Closure of universities due to Coronavirus Disease 2019 (COVID-19): impact on education and mental health of students and academic staff. Cureus. 2020;12(4).

14. Machado RA, Bonan PR, Perez DE, Martelli Júnior H. COVID-19 pandemic and the impact on dental education: discussing current and future perspectives. Brazilian oral research. 2020;34. 
15. Deery C. The COVID-19 pandemic: implications for dental education. Evidence-based dentistry. 2020;21(2):46-7.

16. Chang TY, Hong G, Paganelli C, Phantumvanit P, Chang WJ, et al. Innovation of dental education during COVID-19 pandemic. Journal of Dental Sciences. 2020;19.

17. Vergara-Buenaventura A, Chavez-Tuñon M, Castro-Ruiz C. The Mental Health Consequences of COVID19 pandemic in Dentistry. Disaster Medicine and Public Health Preparedness. 2020;5:1-3.

18. González-Olmo MJ, Ortega-Martínez AR, Delgado-Ramos B, Romero-Maroto M, Carrillo-Diaz M. Perceived vulnerability to Coronavirus infection: impact on dental practice. Brazilian Oral Research. 2020;34.

19. Desai BK. Clinical implications of the COVID-19 pandemic on dental education. Journal of Dental Education. 2020;84(5):512.

20. Stewart J, O'Halloran C, Barton JR, Singleton SJ, Harrigan P, Spencer J. Clarifying the concepts of confidence and competence to produce appropriate self-evaluation measurement scales. Med Educ. 2000;34(11):903-9.

21. Manakil J, George R. Self-perceived work preparedness of the graduating dental students. Eur J Dent Educ. 2013;17(2):101-5.

22. Schönwetter DJ, Law D, Mazurat R, Sileikyte R, Nazarko O. Assessing graduating dental students' competencies: The impact of classroom, clinic and externships learning experiences. Eur J Dent Educ. 2011;15(3):142-52.

23. Ali K, Slade A, Kay E, Zahra D, Tredwin C. Preparedness of undergraduate dental students in the United Kingdom: A national study. Br Dent J. 2017;222(6):472-7.

24. Razak IA, Latifah RRJ, Jaafar N, Abu Hassan MI, Ab Murat N. Assessing the competency of University of Malaya dental graduates: employers' and graduates' perceptions. J Dent Educ. 2008;72(3):364-9.

25. Al-Asmar AA, Sabra AH, Sawair F, Baqain ZH. The correlation between academic and practical achievements of a group of Jordanian dental students. Jordan Medical Journal. 2017;51(1):15-23.

\section{Tables}

Table 1: Descriptive statistics of TPS according to class of participants.

\begin{tabular}{|l|l|l|l|}
\hline Class & TPS & Range of MPS & P value* \\
& Mean \pm SD & & \\
\hline Graduating in 2020 & $98.1 \pm 9.9$ & $69-120$ & \multirow{2}{*}{0.032} \\
\cline { 1 - 3 } Graduated in 2019 & $95.1 \pm 8.6$ & $75-114$ & \\
\cline { 1 - 3 } Graduated before 2019 & $99.5 \pm 10.1$ & $71-115$ & \\
\hline
\end{tabular}

TPS: total preparedness score. * One-Way-ANOVA test 
Table 2: The response of the different graduates to each competency. 


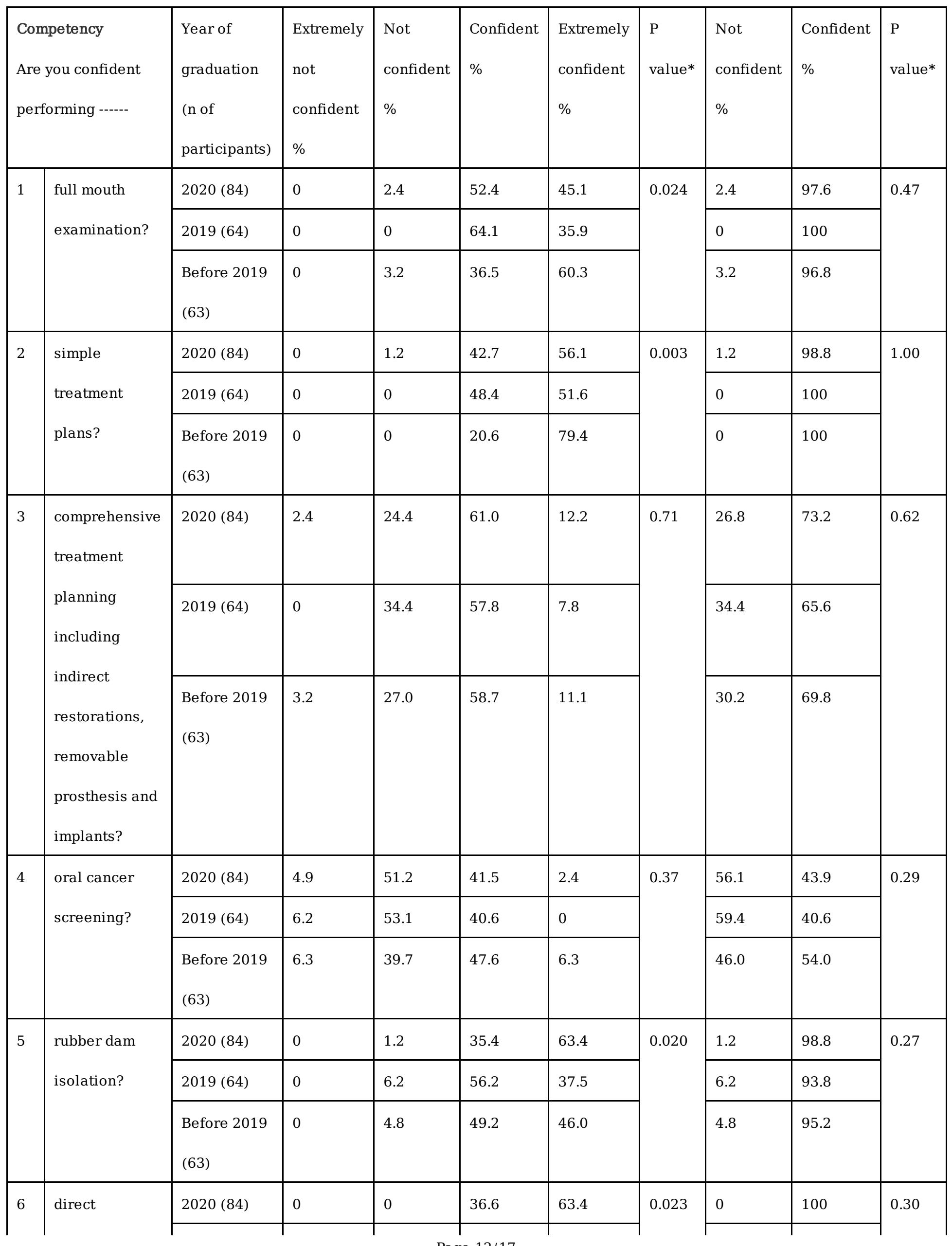




\begin{tabular}{|c|c|c|c|c|c|c|c|c|c|c|}
\hline & \multirow[t]{2}{*}{ restorations? } & 2019 (64) & 0 & 0 & 53.1 & 46.9 & & 0 & 100 & \\
\hline & & $\begin{array}{l}\text { Before } 2019 \\
\text { (63) }\end{array}$ & 0 & 1.6 & 30.2 & 68.3 & & 1.6 & 98.4 & \\
\hline \multirow[t]{3}{*}{7} & \multirow{3}{*}{$\begin{array}{l}\text { full coverage } \\
\text { crown } \\
\text { preparation? }\end{array}$} & $2020(84)$ & 1.2 & 15.9 & 51.2 & 31.7 & \multirow[t]{3}{*}{0.042} & 17.1 & 82.9 & \multirow[t]{3}{*}{0.60} \\
\hline & & 2019 (64) & 1.6 & 18.8 & 70.3 & 9.4 & & 20.3 & 79.7 & \\
\hline & & Before 2019 & 1.6 & 22.2 & 47.6 & 28.6 & & 23.8 & 76.2 & \\
\hline \multirow[t]{3}{*}{8} & \multirow{3}{*}{$\begin{array}{l}\text { provisional } \\
\text { restoration? }\end{array}$} & $2020(84)$ & 0 & 11.0 & 58.5 & 30.5 & \multirow[t]{3}{*}{0.27} & 11.0 & 89.0 & \multirow[t]{3}{*}{0.26} \\
\hline & & 2019 (64) & 0 & 14.1 & 67.2 & 18.8 & & 14.1 & 85.9 & \\
\hline & & Before 2019 & 0 & 20.6 & 54.0 & 25.4 & & 20.6 & 79.4 & \\
\hline \multirow[t]{3}{*}{9} & \multirow{3}{*}{$\begin{array}{l}\text { final } \\
\text { impression? }\end{array}$} & $2020(84)$ & 0 & 12.2 & 57.3 & 30.5 & \multirow[t]{3}{*}{0.34} & 12.2 & 87.8 & \multirow[t]{3}{*}{0.65} \\
\hline & & 2019 (64) & 1.6 & 10.9 & 68.8 & 18.8 & & 12.5 & 87.5 & \\
\hline & & Before 2019 & 0 & 7.9 & 58.7 & 33.3 & & 7.9 & 92.1 & \\
\hline \multirow[t]{4}{*}{10} & \multirow{2}{*}{$\begin{array}{l}\text { Root Canal } \\
\text { Treatment for }\end{array}$} & $2020(84)$ & 0 & 0 & 23.2 & 76.8 & \multirow[t]{4}{*}{0.055} & 0 & 100 & \multirow[t]{4}{*}{1.0} \\
\hline & & 2019 (64) & 0 & 0 & 35.9 & 64.1 & & 0 & 100 & \\
\hline & a single root & Before 2019 & 0 & 0 & 41.3 & 58.7 & & 0 & 100 & \\
\hline & tooth? & (63) & & & & & & & & \\
\hline \multirow[t]{3}{*}{11} & \multirow{3}{*}{$\begin{array}{l}\text { Root Canal } \\
\text { Treatment for }\end{array}$} & $2020(84)$ & 0 & 12.2 & 69.5 & 18.3 & \multirow[t]{3}{*}{0.004} & 12.2 & 87.8 & \multirow[t]{3}{*}{0.001} \\
\hline & & 2019 (64) & 1.6 & 34.4 & 57.8 & 6.2 & & 35.9 & 64.1 & \\
\hline & & Before 2019 & 1.6 & 34.9 & 47.6 & 15.9 & & 36.5 & 63.5 & \\
\hline \multirow[t]{3}{*}{12} & \multirow{3}{*}{$\begin{array}{l}\text { secondary } \\
\text { impression for }\end{array}$} & $2020(84)$ & 0 & 4.9 & 56.1 & 39.0 & \multirow[t]{3}{*}{0.011} & 4.9 & 95.1 & \multirow[t]{3}{*}{0.028} \\
\hline & & 2019 (64) & 1.6 & 12.5 & 70.3 & 15.6 & & 14.1 & 85.9 & \\
\hline & & $\begin{array}{l}\text { Before } 2019 \\
\text { (63) }\end{array}$ & 1.6 & 17.5 & 52.4 & 28.6 & & 19.0 & 81.0 & \\
\hline \multirow[t]{2}{*}{13} & \multirow{2}{*}{$\begin{array}{l}\text { bite } \\
\text { registration for }\end{array}$} & $2020(84)$ & 0 & 12.2 & 63.4 & 24.4 & \multirow[t]{2}{*}{0.015} & 12.2 & 87.8 & \multirow[t]{2}{*}{0.004} \\
\hline & & & & & & & & & & \\
\hline
\end{tabular}




\begin{tabular}{|c|c|c|c|c|c|c|c|c|c|c|}
\hline & \multirow{2}{*}{$\begin{array}{l}\text { complete } \\
\text { denture } \\
\text { patient? }\end{array}$} & $\begin{array}{l}2019(64) \\
\text { Before } 2019\end{array}$ & $\begin{array}{l}0 \\
1.6\end{array}$ & $\begin{array}{l}34.4 \\
28.6\end{array}$ & $\begin{array}{l}51.6 \\
47.6\end{array}$ & $\begin{array}{l}14.1 \\
22.2\end{array}$ & & $\begin{array}{l}34.4 \\
30.2\end{array}$ & $\begin{array}{l}65.6 \\
69.8\end{array}$ & \\
\hline & & (63) & & & & & & & & \\
\hline 14 & clinical & $2020(84)$ & 8.5 & 47.6 & 39.0 & 4.9 & 0.32 & 56.1 & 43.9 & 0.62 \\
\hline & remount and & 2019 (64) & 7.8 & 51.6 & 39.1 & 1.6 & & 59.4 & 40.6 & \\
\hline & $\begin{array}{l}\text { insertion of a } \\
\text { removable } \\
\text { prosthesis? }\end{array}$ & $\begin{array}{l}\text { Before } 2019 \\
\text { (63) }\end{array}$ & 3.2 & 47.6 & 38.1 & 11.1 & & 50.8 & 49.2 & \\
\hline 15 & surveying and & $2020(84)$ & 3.7 & 28.0 & 50.0 & 18.3 & 0.42 & 31.7 & 68.3 & 0.85 \\
\hline & designing of a & 2019 (64) & 1.6 & 34.4 & 57.8 & 6.2 & & 35.9 & 64.1 & \\
\hline & Co-Cr RPD? & $\begin{array}{l}\text { Before } 2019 \\
\text { (63) }\end{array}$ & 4.8 & 30.2 & 49.2 & 15.9 & & 34.9 & 65.1 & \\
\hline 16 & profound local & $2020(84)$ & 0 & 0 & 53.7 & 46.3 & 0.002 & 0 & 100 & 0.61 \\
\hline & anesthesia? & 2019 (64) & 0 & 1.6 & 35.9 & 62.5 & & 1.6 & 98.4 & \\
\hline & & $\begin{array}{l}\text { Before } 2019 \\
\text { (63) }\end{array}$ & 0 & 0 & 25.4 & 74.6 & & 0 & 100 & \\
\hline 17 & simple non- & $2020(84)$ & 0 & 1.2 & 37.8 & 61.0 & 0.39 & 1.2 & 98.8 & 1.00 \\
\hline & surgical & 2019 (64) & 0 & 1.6 & 43.8 & 54.7 & & 1.6 & 98.4 & \\
\hline & extraction? & $\begin{array}{l}\text { Before } 2019 \\
\text { (63) }\end{array}$ & 0 & 1.6 & 27.0 & 71.4 & & 1.6 & 98.4 & \\
\hline 18 & surgical & $2020(84)$ & 12.2 & 54.9 & 28.0 & 4.9 & 0.082 & 67.1 & 32.9 & 0.061 \\
\hline & extraction? & 2019 (64) & 6.2 & 53.1 & 34.4 & 6.2 & & 59.4 & 40.6 & \\
\hline & & $\begin{array}{l}\text { Before } 2019 \\
\text { (63) }\end{array}$ & 6.3 & 41.3 & 34.9 & 17.5 & & 47.6 & 52.4 & \\
\hline 19 & suturing? & $2020(84)$ & 4.9 & 28.0 & 46.3 & 20.7 & 0.058 & 32.9 & 67.1 & 0.30 \\
\hline & & 2019 (64) & 1.6 & 31.2 & 53.1 & 14.1 & & 32.8 & 67.2 & \\
\hline & & $\begin{array}{l}\text { Before } 2019 \\
\text { (63) }\end{array}$ & 4.8 & 17.5 & 41.3 & 36.5 & & 22.2 & 77.8 & \\
\hline 20 & oral hygiene & $2020(84)$ & 0 & 1.2 & 26.8 & 72.0 & 0.088 & 1.2 & 98.8 & 1.00 \\
\hline & instructions? & 2019 (64) & 0 & 0 & 37.5 & 62.5 & & 0 & 100 & \\
\hline
\end{tabular}




\begin{tabular}{|c|c|c|c|c|c|c|c|c|c|c|}
\hline & & $\begin{array}{l}\text { Before } 2019 \\
\text { (63) }\end{array}$ & 0 & 0 & 19.0 & 81.0 & & 0 & 100 & \\
\hline \multirow[t]{3}{*}{21} & \multirow{2}{*}{$\begin{array}{l}\text { periodontal } \\
\text { examination, }\end{array}$} & $2020(84)$ & 0 & 4.9 & 43.9 & 51.2 & \multirow[t]{3}{*}{0.37} & 4.9 & 95.1 & \multirow[t]{3}{*}{0.94} \\
\hline & & $2019(64)$ & 0 & 6.2 & 59.4 & 34.4 & & 6.2 & 93.8 & \\
\hline & $\begin{array}{l}\text { diagnoses and } \\
\text { treatment } \\
\text { planning? }\end{array}$ & $\begin{array}{l}\text { Before } 2019 \\
\text { (63) }\end{array}$ & 0 & 6.3 & 47.6 & 46.0 & & 6.3 & 93.7 & \\
\hline \multirow[t]{3}{*}{22} & \multirow{3}{*}{$\begin{array}{l}\text { supra and sub- } \\
\text { gingival }\end{array}$} & $2020(84)$ & 0 & 2.4 & 36.6 & 61.0 & \multirow[t]{3}{*}{0.29} & 2.4 & 97.6 & \multirow[t]{3}{*}{0.64} \\
\hline & & $2019(64)$ & 0 & 0 & 51.6 & 48.4 & & 0 & 100 & \\
\hline & & $\begin{array}{l}\text { Before } 2019 \\
\text { (63) }\end{array}$ & 0 & 1.6 & 38.1 & 60.3 & & 1.6 & 98.4 & \\
\hline \multirow[t]{3}{*}{23} & \multirow{3}{*}{$\begin{array}{l}\text { examination } \\
\text { and treatment }\end{array}$} & $2020(84)$ & 0 & 4.9 & 57.3 & 37.8 & \multirow[t]{3}{*}{0.001} & 4.9 & 95.1 & \multirow[t]{3}{*}{0.22} \\
\hline & & $2019(64)$ & 0 & 0 & 70.3 & 29.7 & & 0 & 100 & \\
\hline & & $\begin{array}{l}\text { Before } 2019 \\
\text { (63) }\end{array}$ & 0 & 3.2 & 36.5 & 60.3 & & 3.2 & 96.8 & \\
\hline \multirow[t]{3}{*}{24} & oral hygiene & $2020(84)$ & 0 & 6.1 & 43.9 & 50.0 & \multirow[t]{3}{*}{0.041} & 6.1 & 93.9 & \multirow[t]{3}{*}{0.19} \\
\hline & and dietary & 2019 (64) & 0 & 0 & 54.7 & 45.3 & & 0 & 100 & \\
\hline & $\begin{array}{l}\text { advice for a } \\
\text { pediatric } \\
\text { patient? }\end{array}$ & $\begin{array}{l}\text { Before } 2019 \\
\text { (63) }\end{array}$ & 0 & 4.8 & 31.7 & 63.5 & & 4.8 & 95.2 & \\
\hline \multirow[t]{3}{*}{25} & \multirow{2}{*}{$\begin{array}{l}\text { fissure sealant } \\
\text { of a first }\end{array}$} & $2020(84)$ & 0 & 1.2 & 28.0 & 70.7 & \multirow[t]{3}{*}{0.77} & 1.2 & 98.8 & \multirow[t]{3}{*}{1.00} \\
\hline & & $2019(64)$ & 0 & 0 & 29.7 & 70.3 & & 0 & 100 & \\
\hline & $\begin{array}{l}\text { permanent } \\
\text { molar? }\end{array}$ & $\begin{array}{l}\text { Before } 2019 \\
\text { (63) }\end{array}$ & 0 & 0 & 22.2 & 77.8 & & 0 & 100 & \\
\hline 26 & restorations on & $2020(84)$ & 0 & 1.2 & 41.5 & 57.3 & \multirow[t]{2}{*}{0.31} & 1.2 & 98.8 & \multirow[t]{2}{*}{1.00} \\
\hline & a primary & $2019(64)$ & 0 & 1.6 & 54.7 & 43.8 & & 1.6 & 98.4 & \\
\hline
\end{tabular}




\begin{tabular}{|c|c|c|c|c|c|c|c|c|c|c|}
\hline & tooth? & $\begin{array}{l}\text { Before } 2019 \\
\text { (63) }\end{array}$ & 0 & 1.6 & 36.5 & 61.9 & & 1.6 & 98.4 & \\
\hline \multirow[t]{3}{*}{27} & \multirow{3}{*}{$\begin{array}{l}\text { extraction of a } \\
\text { primary tooth? }\end{array}$} & $2020(84)$ & 0 & 2.4 & 46.3 & 51.2 & \multirow[t]{3}{*}{0.01} & 2.4 & 97.6 & \multirow[t]{3}{*}{0.34} \\
\hline & & 2019 (64) & 0 & 0 & 35.9 & 64.1 & & 0 & 100 & \\
\hline & & $\begin{array}{l}\text { Before } 2019 \\
\text { (63) }\end{array}$ & 0 & 0 & 23.8 & 76.2 & & 0 & 100 & \\
\hline \multirow[t]{3}{*}{28} & assessment of & $2020(84)$ & 1.2 & 6.1 & 65.9 & 26.8 & \multirow[t]{3}{*}{0.14} & 7.3 & 92.7 & \multirow[t]{3}{*}{0.83} \\
\hline & teeth & 2019 (64) & 0 & 7.8 & 68.8 & 23.4 & & 7.8 & 92.2 & \\
\hline & $\begin{array}{l}\text { malalignment } \\
\text { problem which } \\
\text { needs an } \\
\text { orthodontic } \\
\text { treatment by } \\
\text { an } \\
\text { orthodontist? }\end{array}$ & $\begin{array}{l}\text { Before } 2019 \\
\text { (63) }\end{array}$ & 1.6 & 3.2 & 50.8 & 44.4 & & 4.8 & 95.2 & \\
\hline \multirow[t]{3}{*}{29} & referral of your & $2020(84)$ & 0 & 1.2 & 42.7 & 56.1 & \multirow[t]{3}{*}{0.38} & 1.2 & 98.8 & \multirow[t]{3}{*}{0.76} \\
\hline & $\begin{array}{l}\text { specialist } \\
\text { when the }\end{array}$ & 2019 (64) & 0 & 0 & 48.4 & 51.6 & & 0 & 100 & \\
\hline & $\begin{array}{l}\text { procedure is } \\
\text { beyond your } \\
\text { scope of skills } \\
\text { and expertise? }\end{array}$ & $\begin{array}{l}\text { Before } 2019 \\
\text { (63) }\end{array}$ & 0 & 1.6 & 31.7 & 66.7 & & 1.6 & 98.4 & \\
\hline \multirow[t]{3}{*}{30} & proper & $2020(84)$ & 1.2 & 4.9 & 45.1 & 48.8 & \multirow[t]{3}{*}{0.46} & 6.1 & 93.9 & \multirow[t]{3}{*}{0.20} \\
\hline & communication & 2019 (64) & 1.6 & 3.1 & 56.2 & 39.1 & & 4.7 & 95.3 & \\
\hline & skills? & $\begin{array}{l}\text { Before } 2019 \\
\text { (63) }\end{array}$ & 0 & 0 & 57.1 & 42.9 & & 0 & 100 & \\
\hline
\end{tabular}

*P value of Chi square test 


\section{Figures}

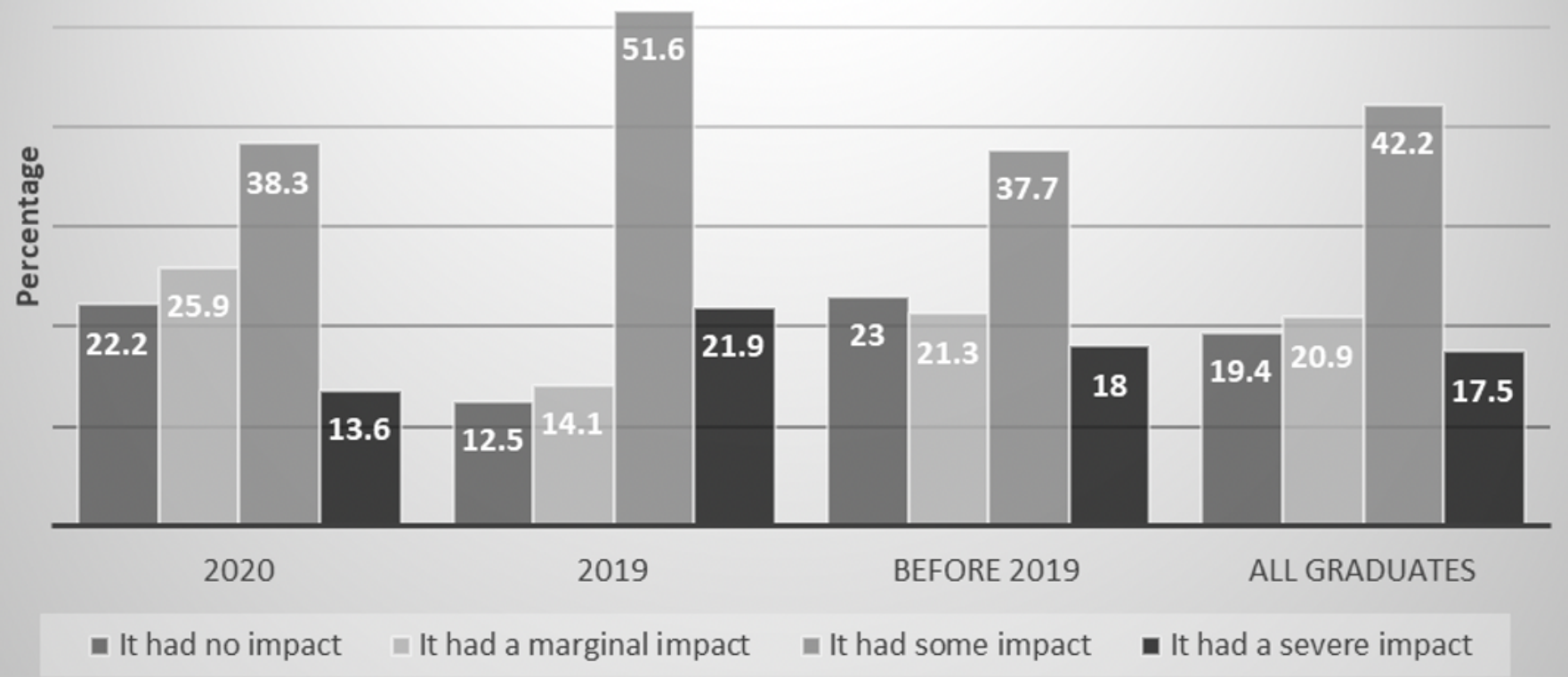

\section{Figure 1}

the impact of COVID-19 pandemic on graduates' confidence in performing general dentistry procedures.

\section{Supplementary Files}

This is a list of supplementary files associated with this preprint. Click to download.

- APPENDIX.docX 